\title{
Management of the poultry red mite, Dermanyssus gallinae, using silica-based acaricides
}

\author{
Christian Ulrichs ${ }^{1}$ (D) Young Jong Han ${ }^{1} \cdot$ Magdi T. Abdelhamid ${ }^{2} \cdot$ Inga Mewis $^{1}$
}

Received: 31 December 2019 / Accepted: 27 August 2020 / Published online: 8 September 2020 (c) The Author(s) 2020

\begin{abstract}
Four silica-based acaricides were examined in laboratory tests for their effectiveness against poultry red mite, Dermanyssus gallinae. All acaricides resulted in 100\% mite mortality. Two groups of active ingredients could be differentiated. The products Silicosec ${ }^{\circledR}$ and Ewazid ${ }^{\circledR}$, based on naturally occurring diatomaceous earth (DE), killed $100 \%$ of adult D. gallinae within $48 \mathrm{~h}$ exposure time. The time to kill $50 \%$ of the mites $\left(\mathrm{LT}_{50}\right)$ was calculated to be 31.7 and $34.9 \mathrm{~h}$, respectively. The other two products, containing aggregates and agglomerates of pyrogenic synthetic amorphous silicon dioxide as active ingredients, killed the mites in a significantly shorter time: $\mathrm{LT}_{50}$ was $6.3 \mathrm{~h}$ for the liquid product Fossil Shield ${ }^{\circledR}$ Instant White and $11.8 \mathrm{~h}$ for the powdery product Fossil Shield 90.0 White. This is more remarkable as the quantities of active ingredients used for the DE treatments were several folds higher. The effectiveness of all tested products was also shown in practical tests. A professional company treated five chicken houses on one farm in the BerlinBrandenburg region with the test products, three houses with Fossil Shield Instant White and one each with Ewazid and Silicosec. Over a period of 46 weeks after stocking, the mite development in the houses was assessed. Only in one of the houses, treated with Fossil Shield Instant White, the mite population remained permanently low. In two houses treated with Fossil Shield Instant White, small mite colonies appeared in week 36, which were controlled by a follow-up spot treatment in week 41 . In the houses treated with DE, the first mite colonies appeared 12 weeks after stocking. The number increased continuously over the experimental period and in week 31 after stocking there were clearly visible colonies (2-3 cm diameter) and the first mites could also be detected on the chicken eggs. At this time both houses were treated again with a follow-up spot-treatment, which only led to a slight improvement in one house and to a stabilization of the infestation in the other house. In week 41, large mite colonies were detected in both houses. A spot treatment at this point was ineffective in reducing the infestation. The tests showed faster acaricidal action of the products with the synthetic active ingredients compared to the natural DE-based products. This matches the shorter killing times under laboratory conditions. The experiments in a commercial chicken farm showed that it is possible to control the mite population for a period of 46 weeks by using physically effective $\mathrm{SiO}_{2}$-based products. These products are therefore an effective alternative to the use of chemical acaricides.
\end{abstract}

Extended author information available on the last page of the article 
Keywords Chicken · Poultry $\cdot$ Ectoparasite $\cdot$ Pest control $\cdot$ Physical acaricides $\cdot$ Synthetic amorphous silicon dioxide

\section{Introduction}

The poultry red mite, Dermanyssus gallinae, is the most important pest in egg-laying hens in many parts of the world (Sparagano et al. 2009; Wang et al. 2010). Even if in some countries other mite species are more important (Wales et al. 2010), in many countries (including Germany) D. gallinae tends to predominate. In the European Union (EU) most of the commercial egg-laying facilities are infested with D. gallinae. For example, Flochlay et al. (2017) reported, that $83 \%$ of the EU farms are infested by D. gallinae. Fiddes et al. (2005) reported an infestation rate of $62 \%$ of egg-laying hen farms for the UK and Mul (2016) reported infestation rates up to $94 \%$ for The Netherlands, Germany and Belgium.

Several authors report a relationship between D. gallinae infestation and hen mortality, under severe infestations causing hens to become anemic (Kilpinen et al. 2005; Wojcik et al. 2000). The economic costs associated with losses in hen productivity and hen mortality has been estimated to be 130 million Euro per year in the EU alone (Sparagano et al. 2009). Other negative effects of infestations include reduced animal welfare, reduced egg quality, and lower bird weight (Chauve 1998).

Research concerning all aspects of $D$. gallinae has increased in recent years. Commonly the pest is controlled using synthetic acaricides with over 35 compounds tested (Sparagano et al. 2014). However, only few products are licensed in the EU. At the same time, residues in laying hens prove that there are more products applied (Marangi et al. 2012). In many countries, resistance to synthetic acaricides in several chemical groups, mainly carbamates and pyrethroids, has been reported (Beugnet et al. 1997; Marangi et al. 2009; Nordenfors et al. 2001). In a British survey published in 2004, more than $60 \%$ of all farms surveyed had experienced acaricide resistant infestations (Guy et al. 2004). The use of synthetic products is further limited due to stricter legislation leading to a reduced number of products in the EU in recent years (Sparagano et al. 2014). Meanwhile, few new synthetic acaricides like the phoxim-based product ByeMite (Bayer, Germany) are being developed against D. gallinae. Whereas initial reports stated a high efficacy (Keita et al. 2006; MeyerKühling et al. 2007), resistance has already been assumed in Poland (Zdybel et al. 2011). Consumer awareness and the demand for pesticide-free products are pushing the search for alternative management strategies away from synthetics.

Silica-based products (silicas) contain mainly silicon dioxide $\left(\mathrm{SiO}_{2}\right)$ as a biocidal substance. They are among the remaining options to control D. gallinae (Kilpinen and Steenberg 2009; Maurer et al. 2009). Both natural and synthetic silica products are applied for pest control. Synthetic products contain exclusively amorphous $\mathrm{SiO}_{2}$ whereas natural products have been mainly based on diatomaceous earth (DE) which contains a small crystalline fraction. Amorphous silica is 'generally considered safe' by the US Federal Drug Administration, and amorphous silica nanoparticles are often used as 'negative controls' in toxicity studies of nanocrystalline quartz (Ghiazza et al. 2010). The efficacy of silica products against arthropods varies widely (Mucha-Pelzer et al. 2008). Studies show that correlations exist between the insecticidal/acaricidal efficacy and the absorption capacity of the particles (Faulde et al. 2006; Schulz et al. 2014), chemical composition (Ulrichs et al. 2008), particle size (Arnaud et al. 2005), and specific surface (Islam et al. 2010). In the early days of application when mainly natural $\mathrm{SiO}_{2}$ products (DE) were used, they were 
surface-treated to make them water-repellent and therefore more effective. Today we see increasing use of purely synthetic compounds coming onto the market.

The purpose of the present study was (1) to compare new synthetic silica-based products with products based on DE, (2) to identify the most effective materials in laboratory tests, and (3) to indicate their efficacy under field conditions in a commercial hen house.

\section{Materials and methods}

\section{Test substances}

All test products are commercially available from various producers. Table 1 shows products tested in laboratory experiments. Silicosec ${ }^{\circledR}$ (100 g powder in $600 \mathrm{ml}$ water), Ewazid ${ }^{\circledR}$ Silgur F46 (100 g powder in $600 \mathrm{ml}$ water), and Fossil Shield ${ }^{\circledR}$ Instant White (100 g powder in $800 \mathrm{ml}$ water) were prepared as recommended by the producer. Fossil Shield 90.0 White was applied as a powdery dry material.

\section{Laboratory experiments}

The experiments were carried out under controlled climatic conditions $\left(25^{\circ} \mathrm{C}, 80 \%\right.$ relative humidity) in a Conviron MTR26 plant growth cabinet (Winnipeg, Canada) at HumboldtUniversität zu Berlin, Germany. All experiments were conducted with mites in open plastic Petri dishes ( $9 \mathrm{~cm}$ diameter). By using open dishes, the climate corresponded to the conditions set in the plant growth cabinet.

The inside base of the Petri dishes used were ground to roughen the surface for better adhesion of the test substances. Grinding residues were removed with the help of compressed air. To prepare the fluid products, the powdery test substances were mixed in water. Mixing was carried out using a Collomix DLX $152 \mathrm{~m}$ and a standard drill. The test substances were stirred into water and the sample taken for application into the empty Petri dishes. The powdery test substance was transferred into the Petri dishes with the aid of a

Table 1 Test products, mean active substances and calculated mean amount for applications

\begin{tabular}{|c|c|c|c|c|}
\hline Product [CAS number] & $\begin{array}{l}\text { Dried product } \\
(\mathrm{mg} / \text { dish })^{\mathrm{d}}\end{array}$ & $\begin{array}{l}\text { Active substance } \\
(\mathrm{mg} / \mathrm{dish})^{\mathrm{d}}\end{array}$ & Product $\left(\mathrm{g} / \mathrm{m}^{2}\right)$ & $\begin{array}{l}\text { Active } \\
\text { substance }(\mathrm{g} / \\
\left.\mathrm{m}^{2}\right)\end{array}$ \\
\hline $\begin{array}{l}\text { Fossil Shield }^{\circledR} 90.0 \text { White }^{\mathrm{a}} \\
{[68909-20-6]}\end{array}$ & 112 & 5.028 & 18.63 & 0.836 \\
\hline $\begin{array}{l}\text { Fossil Shield }^{\circledR} \text { Instant White } \\
\text { [68909-20-6] }\end{array}$ & 247 & 17.78 & 41.07 & 2.96 \\
\hline $\begin{array}{l}\text { Silicosec }{ }^{\circledR} \text { fluid }^{\mathrm{c}} \\
{[61790-53-2]}\end{array}$ & 440 & 440 & 73.17 & 73.17 \\
\hline $\begin{array}{l}\text { Ewazid }^{\circledR} \text { Silgur F46 } \\
{[61790-53-2]}\end{array}$ & 258 & 258 & 42.91 & 42.91 \\
\hline
\end{tabular}

${ }^{\mathrm{a}} 4.5 \%$ and ${ }^{\mathrm{b}} 7.2 \%$ active ingredient pyrogenic, synthetic amorphous $\mathrm{SiO}_{2}$ (aggregates and agglomerates in nanoform); ${ }^{\mathrm{c}} 100 \%$ diatomaceous earth as active ingredient

${ }^{\mathrm{d}}$ Surface of the dish was $60.13 \mathrm{~cm}^{2}$ 
brush and weighed in. An attempt was made to achieve an even coating of the surface by gently shaking the dish.

Six Petri dishes were coated for each of the test substances and the four dishes with the most uniform coating were selected. Each Petri dish was counted as a replication. The liquid products were applied with the aid of a Birchmeier Spray-Matic 1.25 N, a full cone nozzle and a pressure of 3 bar from a distance of approximately $30-40 \mathrm{~cm}$. The liquidcoated dishes were stored at room temperature for drying. After drying, excess material was removed from the edge of the dishes and the trays were weighed to calculate the quantities used. The edge of the Petri dishes was coated with non-stick substance (provided by Bein, Eiterfeld, Germany). This coating prevents mites from leaving the open Petri dish. The dry dishes were adapted to the climatic conditions in the experiment $48 \mathrm{~h}$ before mites were introduced. Untreated Petri dishes served as control.

All experiments were executed in dark conditions, which is the natural condition of a nocturnal food search for D. gallinae. Mites were not fed during the laboratory experiments. A mixed population of D. gallinae was collected in a chicken house 1 day before the experiment. In the chicken house mite colonies were found especially near the approach plates, at corners and edges near the resting places of the hens. Until treatment the mites were adapted to the experimental climate conditions in the same plant growth cabinet where the experiments took place. Mites were then transferred to the Petri dishes in the laboratory directly before the test. For this purpose, a stick was held in the vessel with mites. The mites migrated up the stick, which meant that only vigorous mites were tested. The migrating mites were transferred to the prepared test Petri dishes by tapping the rod vigorously. Therefore, all developmental stages which could hold on to the stick took part in the experiment. These are predominantly protonymphal and deutonymphal stages and adult mites. Small larvae, freshly hatched, would not be able to hold as well to the stick compared to older stages, and eggs were also thus excluded. Altogether, a minimum of 30 individual developed mites were transferred into each Petri dish.

Mortality rates were controlled under a stereoscopic microscope over a period of $48 \mathrm{~h}$. To facilitate control, the mites were moved to one side of the dish by holding the Petri dish at an angle and tapping on the side. This facilitated counting and enabled a comparison of mite conditions, as vigorous mites can adhere well to most surfaces. However, as soon as they are only 'partially vital', this characteristic is lost. During the control, the mites were only declared 'dead' if there was no more self-motion visible. Some of them remained motionless for a long time and then began to walk again. A good indication of the death of the animals is the curvature of the legs towards the corpus, which is typical for arthropods, and a sunken and noticeably less shiny body. Furthermore, it was observed that the digestion process of the mites always slowed down during exposure and finally came to a standstill. In unclear physical condition, the Petri dish was slightly tapped, which prompted living poultry red mites to move.

\section{Field experiments}

To test the efficacy under real conditions, a practical trial in 2017 compared the synthetic silica-based Fossil Shield Instant White with two DE products Silicosec and Ewazid Silgur-F46. The application was carried in five wet-cleaned and disinfected houses of a commercial laying hen farm in Brandenburg, Germany. Four houses were $1000 \mathrm{~m}^{2}$, one $950 \mathrm{~m}^{2}$. The density of chickens for housing was $15 \mathrm{hens} / \mathrm{m}^{2}$ accessible area. Chickens of the Lohmann brown breed were kept at $16-32{ }^{\circ} \mathrm{C}$ and $65-80 \% \mathrm{RH}$. Light was 
given according to the course of a day and in accordance with the management guide by Garrelfs et al. (2016). The animals were kept in floor management in so-called multitier aviaries. The tiers provide living space at several levels, allowing hens to disperse across levels. This way the tiers increase the total accessible area (max. 4 tiers according to EU Directive), enabling higher stocking densities compared to conventional floor housing. The aviaries were made of metal. Wood shavings were used as bedding material and renewed twice a week.

Treatment of the houses took place on 9 November 2016 and 3 days later the chickens were housed. The occurrence of mites in the houses was assessed at 12, 27, 31, 36, 41 , and 46 weeks after treatment. No mite traps were used to monitor the population development, but fixed sample sites were examined. We decided against the use of traps because although they are very suitable for indicating the presence of mites, they are less suitable for quantification. Observations in the past have often shown that the mites stayed near but not in the traps, therefore not reflecting the intensity of the infestation.

Five sample sites were selected for each house segment. One house segment is approx. $3 \mathrm{~m}$ long. In the houses there are 50 segments each in two frames, every 4 th segment was evaluated. With the help of an illuminated telescope mirror, it was possible to check areas difficult to access for mite infestation. In particular, the undersides of the approach plates, cross and longitudinal beams of the house, perches, connecting pieces to drinking lines as well as the entire head on both sides of the house were examined. In addition, the manure belt, ventilation systems, and the pipes of the perch rods, some of which were not closed at the head, were inspected by video endoscopy. The mite development was evaluated on a scale from 0 to 5 (Table 2) over a period of 46 weeks (Fig. 2).

In the field tests, the liquid products were applied according to the manufacturer's specifications by means of a diaphragm pump system and spray nozzles for every layer of the structure. For the product Silicosec $1200 \mathrm{l}$ was applied in the stable on $950 \mathrm{~m}^{2}$. The product Ewazid Silgur F46 was applied with 10501 on a surface of $1000 \mathrm{~m}^{2}$ and Fossil Shield Instant White with 8801 per $1000 \mathrm{~m}^{2}$ surface. The application system was designed in such a way that all the levels of the house were coated with test material. After drying, before stocking the hens, a dense dry product film remained on the surfaces. During stocking with hens this coating wears out. When the first mite colonies (score 2, Table 2) reappeared, a specific treatment of the mite population took place in these houses. This selective spot-treatment took place with a simple backpack sprayer. Only spots with visible mite colonies were treated.

Table 2 Score to estimate mite population in houses

\section{No mites}

1 Individual mites, without colonies (usually beginning at the head parts of the house)

2 Approx. 5-7 colonies the size of a pinhead (on headboards and 10\% of the house segments [front plates, very hidden])

$3>10$ colonies the size of a thumbnail in $100 \%$ of the segments, visible on anterior and middle plates and supports

$4>15$ well visible colonies (2-3 cm diameter) in the complete house, beginning behavioral abnormality in hens, sporadic mites when collecting eggs for the first time in the morning

5 Large mite colonies on the complete house, mite odor, anemia, behavioral abnormalities, mites on the eggs, increased hen mortality 
In two houses treated with DE (1 and 2), a first follow-up treatment was carried out after 31 weeks. In houses 1, 2, 3 and 5 the follow-up treatment was carried out after 41 weeks. Only in house 4 no significant colonies were identified and therefore no follow-up treatment was carried out.

\section{Statistical evaluation}

The statistics software package SPSS v.25 was used. A General Linear Model was used to search for deviations between the mean values after $24 \mathrm{~h}$ exposure time. Tukey's honestly significant difference (HSD) test was used to separate mean values among the test substances for the examination after $24 \mathrm{~h}(\alpha=0.05)$. The time at which $50 \%$ and $90 \%$ of the mites died after treatment $\left(\mathrm{LT}_{50}\right.$ and $\left.\mathrm{LT}_{90}\right)$ was determined by probit analysis. Abbott (1925) correction of the data was waived in the lab experiments, but the mortality rate in the controls were reported. The field trials could not be evaluated statistically due to a lack of repetition for Silicosec and Ewazid.

\section{Results}

\section{Laboratory experiments}

Twenty-four $\mathrm{h}$ after treatment with both Fossil Shield formulations mite mortality reached $100 \%$ under laboratory conditions (Fig. 1). Treatment with Silicosec and

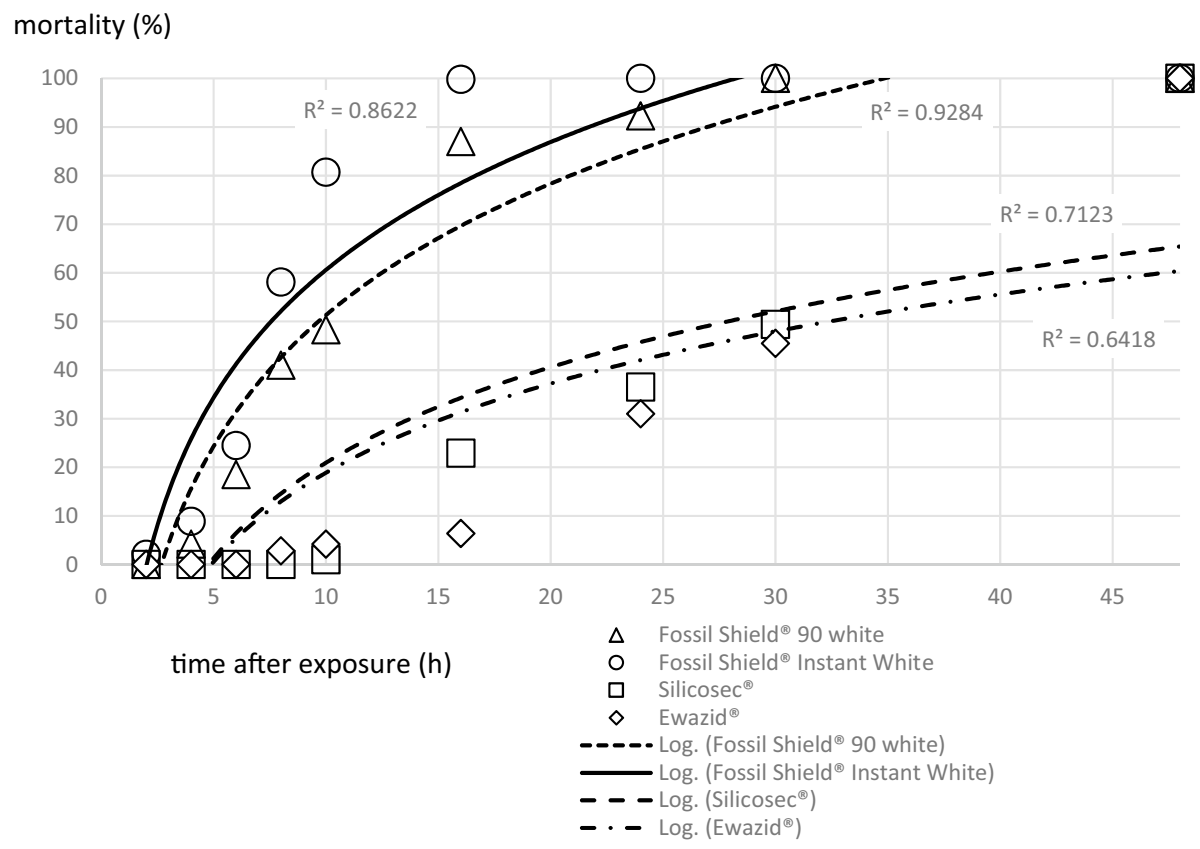

Fig. 1 Dermanyssus gallinae cumulative mortality over time after treatment with each of four test substances 
Ewazid caused an average mortality after $24 \mathrm{~h}$ of 36.5 and $31 \%$, respectively; however, $100 \%$ of all mites were killed within $48 \mathrm{~h}$ after treatment (Fig. 1).

All treatments increased mortality within $24 \mathrm{~h}$ significantly (Fig. 1). There was no difference in efficacy within active ingredient group (DE vs. pyrogenic, synthetic amorphous, surface-treated $\mathrm{SiO}_{2}$ ) (Table 3). However, the synthetic silica products (Fossil Shield) were more effective after $24 \mathrm{~h}$ of exposure compared to the natural products (Ewazid and Silicosec) (Table 3). Control mortality was $3.85 \%$ after $24 \mathrm{~h}$ of exposure and $4.8 \%$ after $48 \mathrm{~h}$.

Table 3 Cumulative mortality (\%) for Dermanyssus gallinae after 24 and $48 \mathrm{~h}$ of exposure to each of four silica-based acaricides under laboratory conditions

\begin{tabular}{llllll}
\hline $\begin{array}{l}\text { Exposure } \\
\text { time (h) }\end{array}$ & Control & $\begin{array}{l}\text { Fossil } \\
\text { Shield } 90 \\
\text { white }\end{array}$ & $\begin{array}{l}\text { Fossil Shield } \\
\text { Instant White }\end{array}$ & Silicosec & Ewazid \\
\hline 24 & $3.85 \mathrm{a}$ & $92.3 \mathrm{c}$ & $100 \mathrm{c}$ & $36.5 \mathrm{~b}$ & $31.0 \mathrm{~b}$ \\
48 & $4.80 \mathrm{a}$ & $100 \mathrm{~b}$ & $100 \mathrm{~b}$ & $100 \mathrm{~b}$ & $100 \mathrm{~b}$ \\
\hline
\end{tabular}

Different letters following means within a row indicate significant differences among products (Tukey's HSD: $\mathrm{p}<0.05$ )

Table 4 Lethal time (h) after which $50 \%\left(\mathrm{LT}_{50}\right)$ or $90 \%\left(\mathrm{LT}_{90}\right)$ of all mites have been killed (95\% confidence intervals in parentheses), determined by probit analysis, for the test substances

\begin{tabular}{lcc}
\hline Product & $\mathrm{LT}_{50}$ & $\mathrm{LT}_{90}$ \\
\hline Fossil Shield 90.0 White & $11.821(10.881-13.879)$ & $19.247(18.548-21.082)$ \\
Fossil Shield Instant White & $6.357(5.077-7.634)$ & $9.396(8.027-12.414)$ \\
Silicosec & $31.706(25.720-44.086)$ & $52.416(41.098-76.449)$ \\
Ewazid & $34.988(28.447-46.288)$ & $55.874(42.264-79.101)$ \\
\hline
\end{tabular}

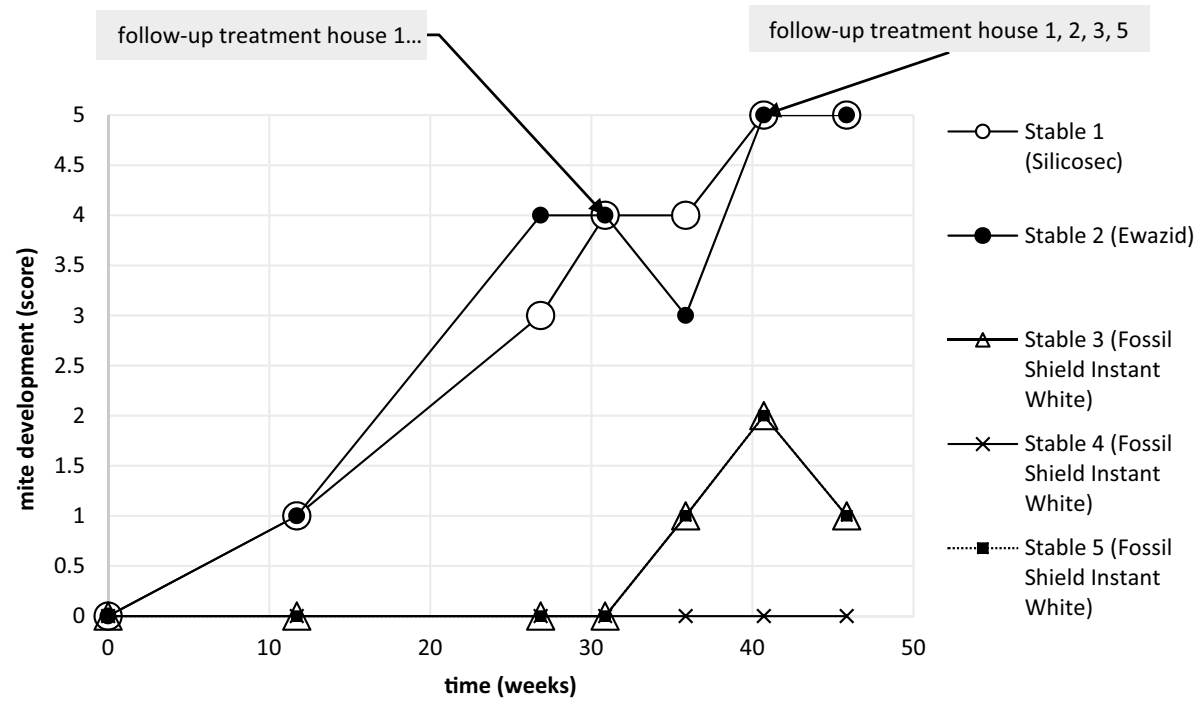

Fig. 2 Mite development (based on mite presence scores; see Table 2) over 46 weeks in five houses (stables), each treated with one silica product, after chickens were housed (9 November 2016) 
The comparison of the $\mathrm{LT}_{50}$ and $\mathrm{LT}_{90}$ values showed differences in the efficacy of the test substances (Table 4). The most effective test substance was Fossil Shield Instant White with $\mathrm{LT}_{50}=6.4 \mathrm{~h}$ and $\mathrm{LT}_{90}=9.5 \mathrm{~h}$. Fossil Shield 90.0 White killed $50 \%$ after $11.8 \mathrm{~h}$ and $90 \%$ after $18.5 \mathrm{~h}$. For Silicosec $\mathrm{LT}_{50}$ was $31.7 \mathrm{~h}$ and $\mathrm{LT}_{90} 52.4 \mathrm{~h}$, whereas for Ewazid $\mathrm{LT}_{50}$ was $34.9 \mathrm{~h}$ and $\mathrm{LT}_{90} 55.9 \mathrm{~h}$.

\section{Experiments in houses with egg-laying hens}

The development of mite populations in the houses showed large differences depending on the treatment. In the two houses treated with DE-based products, the population increased over the trial period of 46 weeks (Fig. 2). In the three houses where Fossil Shield Instant White was used, there was no population increase during first 31 weeks; however, after 31 weeks, population growth was observed in two houses (Fig. 1).

As the experiments were conducted in commercial production systems, farmers did not want to lose productivity and have therefore treated houses where mite population increased within the observation period. A spot follow-up treatment was applied in houses 1 and 2 with Silicosec and Ewazid, respectively. In house 1 the population did not further increase until week 41, in house 2 the mite population first decreased of the, but recovered by week 41 .

In two houses (3 and 5) initially treated with Fossil Shield Instant White at week 41 the population decreased to a lower score until the last observation date (week 46).

\section{Discussion}

With increasing resistance of $D$. gallinae to synthetic acaricides and changes in legislation and production practices, it is likely that D. gallinae will pose an ever-increasing threat to global poultry production. The fastest and easiest way to control mites in the henhouse is to use chemical agents. However, resistances against acaricides (Murano et al. 2009) and the chemical residue after treatment (Marangi et al. 2012) is viewed critically. Resistances have been reported in many countries and for different groups of active ingredients (Beugnet et al. 1997; Nordenfors et al. 2001). Marangi et al. (2012) tested 45 hens from three farms and found carbaryl residues in over $40 \%$ of their organ and tissue samples, and permethrin residue was detected in nearly $2 \%$ of their samples. Carbaryl is banned by the EU and permethrin not licensed.

For this reason, it is important to search for products that are highly effective while being user-friendly and more environmentally friendly. Physical treatments using chemically inert dusts could make a significant contribution here. Among the best studied inert substances are DE (Mewis and Ulrichs 2001; Islam et al. 2010; Badii et al. 2013), but also kaolin (Mullens et al. 2012) and synthetic silicates (Maurer et al. 2009; Luis et al. 2019) have been used against the poultry red mite D. gallinae. Numerous substances are sold in powder form, but for some years now liquid applications have also been increasingly finding their way into practice. The mechanism of action is mainly due to the absorption of lipids from the epicuticle of the mites, leading to desiccation (Mewis and Ulrichs 2001). 


\section{Comparison of products}

Under laboratory conditions, both Fossil Shield products with the active substance pyrogenic, synthetic amorphous, surface-treated $\mathrm{SiO}_{2}$, lead to a significantly faster killing of $D$. gallinae than the products with DE as active ingredient, Silicosec and Ewazid (Tables 3, 4). However, the tests do not allow conclusions to be drawn about dose-dependent mortality, as various amounts of active ingredients have been applied. Still, the difference between the two active ingredients and their efficacy becomes more apparent, if the quantities of active substance used are considered. For Silicosec and Ewazid the amount of active substance applied was much higher that for the Fossil Shield products (Table 1). In contrast, Fossil Shield products consist of an active substance and a filler. If the filler is removed, only $0.8 \mathrm{mg} \mathrm{m}^{-2}$ active substance was applied for 90.0 White and $2.9 \mathrm{mg} \mathrm{m}^{-2}$ active substance for Instant White. In contrast the DE product did not contain any filler.

Numerous studies have shown that the mortality rate for DE is not very high within a short period after application at high relative humidity (Schulz et al. 2014). Due to microclimatic differences, sub-optimal application of the product to surfaces, and the ability of the mites to absorb food and thus counteract water loss (Schulz et al. 2014), the necessary exposure times in field experiments to kill all mites is longer than under optimal laboratory conditions.

It must be noted that due to the way the mites were introduced into the Petri dishes, no eggs were introduced. Products based on DE have only a minor effect on eggs (Schulz et al. 2014). It is therefore more important that the products exhibit a long-term effect.

\section{Field experiments and practical implications}

All products effectively reduced $D$. gallinae populations in experiments conducted in commercial hen houses. However, there were differences in the effectiveness under these conditions. Here, it is not so much the knock-down effect and rapid effectiveness as in the laboratory tests that play a role, but the long-term control of the mites. Only one of the houses treated with Fossil Shield Instant White had a permanently low mite population over 46 weeks. In two of the houses, small mite colonies first appeared in week 36, which were controlled by follow-up spot treatment in week 41. In contrast to this, the houses treated with Silicosec and Ewazid (both with DE as active ingredient), the first mite colonies appeared 12 weeks after stocking. The number increased continuously over the experimental period and in week 31 after stocking there were clearly visible colonies $(2-3 \mathrm{~cm}$ in diameter) and the first mites could also be detected on the chicken eggs. At this time both houses were treated again with a follow-up spot-treatment, which only led to a slight improvement in one house and to a stabilization of the infestation in the other house. In week 41 large mite colonies were detected in both houses. A spot treatment was not effective in reducing the infestation.

Despite the higher amount of active substance (Table 1), the effectiveness of DE in the practical trials was worse, although we could not run an appropriate statistical analysis. We decided to use whole houses as replicates rather than house segments. Therefore, data are not conclusive for houses treated with Silicosec and Ewazid. An alternative would have been to combine product groups (natural vs. synthetic). But even then, only two houses would have been available as repeats for DE treatment, even though the development of the mite population proved to be similar. In order not to wrongly judge products here, we 
decided to be more reserved in our argumentation. The effectiveness could have been influenced due to the physical properties of the active substances, as the laboratory tests suggest. For a naturally derived product such as DE, efficacy might vary among production batches. Other relevant parameters such as concentration, particle size and adhesion were not collected in the context of this study.

Nevertheless, when Fossil Shield Instant White is used in the house, the mite population was kept very low over a period of 31 weeks and no colonies appeared, only individual mites. With the correct post-treatment of individual mite colonies, directly when they occur, it should be possible to get D. gallinae in the henhouse under control, at least for a longer period without the use of chemicals. In practice, it can be concluded that under the aspects of animal welfare, the use of DE requires earlier post-treatment compared to treatment with synthetic $\mathrm{SiO}_{2}$ products like Fossil Shield Instant White, to keep the mite population low.

The use of smaller amounts of material results in comparatively lower dust exposure and is therefore also safer for the professional user. This is becoming more important in the context of approval in the EU. For example, although the active ingredient $\mathrm{SiO}_{2}$ (DE, synonym Kieselguhr) is approved under the EU Biocide Directive, in November 2016 (Assessment Report 2016), it is stated that "the exposure of professionals to silicon dioxide DE during the large scale dusting in houses leads to an unacceptable risk". This residual risk is due, among other things, to the fact that natural DE, unlike synthetic products, contains a smaller proportion of crystalline $\mathrm{SiO}_{2}$. The Assessment Report (2016) puts this at up to $0.1 \%$. The reduction of dust exposure for the user by a considerably lower application rate is therefore of clear advantage.

It should also be noted that the effectiveness of the silica materials used is reduced at high humidity levels, such as those found in the chicken houses. This can be attributed to two parameters: (1) the water loss of the mites after damage to the epicuticle is reduced, and (2) the partly hydrophobic agents saturate with water and can no longer absorb lipids (Mewis and Ulrichs 2001). At least saturation is not a major problem with synthetic agents, as they are hydrophobic rather than hydrophilic and thus maintain their long-term efficacy. Therefore, companies selling natural DE-based products often blend in hydrophobic synthetic particles to ensure a longer-lasting effect.

Development of more comprehensive IPM regimens for D. gallinae should be facilitated by ongoing developments in monitoring, modeling of populations and management options with new combined materials to minimize the risk of resistance. Methods for monitoring mites in the occupied chicken house, the right application technology and formulations optimized for spot treatment are especially important criteria for future research. In practice, it has often proved to be advantageous to treat the surfaces in the cleaned houses with liquid formulations first. Spot treatments can then be carried out with powdery substances, applied electrostatically, in the occupied houses later to maintain low mite populations.

Funding Open Access funding provided by Projekt DEAL. The authors hereby declare that the research work performed was not funded by industry. The treatments in the hen houses were carried out by a contractor financed by the house owners. The scientists independently investigated the level of mite infestation.

Open Access This article is licensed under a Creative Commons Attribution 4.0 International License, which permits use, sharing, adaptation, distribution and reproduction in any medium or format, as long as you give appropriate credit to the original author(s) and the source, provide a link to the Creative Commons licence, and indicate if changes were made. The images or other third party material in this article are included in the article's Creative Commons licence, unless indicated otherwise in a credit line to the material. If material is not included in the article's Creative Commons licence and your intended use is not 
permitted by statutory regulation or exceeds the permitted use, you will need to obtain permission directly from the copyright holder. To view a copy of this licence, visit http://creativecommons.org/licenses/by/4.0/.

\section{References}

Abbott WS (1925) A method of computing the effectiveness of an insecticide. J Econ Entom 18:265-267

Arnaud L, Tran Thi Lan H, Brostaux Y, Haubruge E (2005) Efficacy of diatomaceous earth formulations admixed with grain against populations of Tribolium castaneum. J Stored Prod Res 2:121-130

Assessment Report (2016) Regulation (EU) No 528/2012 concerning the making available on the market and use of biocidal products. Evaluation of active substances. Silicon dioxide Kieselguhr. https://echa. europa.eu/documents/10162/6bff79eb-7faa-183a-9498-5ca02d5ebe0d. Accessed 24 Dec 2019

Badii BK, Adarklwah C, Obeng-Ofori D, Ulrichs Ch (2013) Efficacy of diatomaceous earth formulations against Callosobruchus maculatus (F.) (Coleoptera: Bruchidae) in Kersting's groundnut (Macrotyloma geocarpum Harms): influence of dosage rate and relative humidity. J Pest Sci 87:285-294

Beugnet F, Chauve C, Gauthey M, Beert L (1997) Resistance of the red poultry mite to pyrethroids in France. Vet Rec 140:577-579

Chauve CM (1998) The poultry red mite Dermanyssus gallinae (De Geer, 1778): current situation and future prospects for control. Vet Parasitol 79:239-245

Faulde MK, Tisch M, Scharninghausen JJ (2006) Efficacy of modified diatomaceous earth on different cockroach species (Orthoptera, Blattellidae) and silverfish (Thysanura, Lepismatidae). J Pest Sci 3:155-161

Fiddes MD, Le Gresley S, Parsons DG, Epe C, Coles GC, Stafford KA (2005) Prevalence of the poultry red mite (Dermanyssus gallinae) in England. Vet Rec 157:233-235

Flochlay AS, Thomas E, Sparagano O (2017) Poultry red mite (Dermanyssus gallinae) infestation: a broad impact parasitological disease that still remains a significant challenge for the egg-laying industry in Europe. Parasit Vectors 10:357

Garrelfs I, Hiller P, Sagkob S, Diekmann L (2016) Minimierung von Federpicken und Kannibalismus bei Legehennen mit intaktem Schnabel: Neue Wege für die Praxis: Managementleitfaden, Landwirtschaftskammer Niedersachsen

Ghiazza M, Polimeni M, Fenoglio I, Gazzano E, Ghigo D, Fubini B (2010) Does vitreous silica contradict the toxicity of the crystalline silica paradigm? Chem Res Toxicol 23:620-629

Guy JH, Khajavi M, Hlalel MM, Sparagano O (2004) Red mite (Dermanyssus gallinae) prevalence in laying units in northern England. Br Poult Sci 45:15-16

Islam S, Md HM, Md, Lei C, Mucha-Pelzer T, Mewis I, Ulrichs Ch (2010) Direct and admixture toxicity of diatomaceous earth and monoterpenoids against the storage pests Callosobruchus maculates (F.) and Sitophilus oryzae (L.). J Pest Sci 83:105-112

Keita A, Pagot E, Pommier P, Baduel L, Heine J (2006) Efficacy of phoxim 50\% E.C. (ByeMite) for treatment of Dermanyssus gallinae in laying hens under field conditions. Revue de médecine vétérinaire 157:590-594

Kilpinen O, Steenberg T (2009) Inert dusts and their effects on the poultry red mite (Dermanyssus gallinae). Exp Appl Acarol 48:51-62

Kilpinen O, Roepstorff A, Permin A, Norgaard-Nielsen G, Lawson LG, Simonsen HB (2005) Influence of Dermanyssus gallinae and Ascaridia galli infections on behaviour and health of laying hens (Gallus gallus domesticus). Br Poult Sci 46:26-34

Luis A, Luis G, Daian O, Pinto K, Cristiane N, Margaret D (2019) Acaricidal activity of inert powders against the poultry red mite Dermanyssus gallinae (DE GEER, 1778) (Mesostigmata: Dermanyssidae). Arch Vet Sci 24:81-92

Marangi M, De Luna CJ, Cafiero MA, Camarda A, Le Bouquin S, Huonnic D, Giangaspero A, Sparangano OA (2009) Phylogenetic relationship between Dermanyssus gallinae populations in European countries based on mitochondrial COI gene sequences. Exp Appl Acarol 48:143-155

Marangi M, Morelli V, Pati S, Camarda A, Cafiero MA, Giangaspero A (2012) Acaricide residues in laying hens naturally infested by red mite Dermanyssus gallinae. PLoS ONE 7:e31795

Maurer V, Perler E, Heckendorn F (2009) In vitro efficacies of oils, silicas and plant preparations against the poultry red mite Dermanyssus gallinae. Exp Appl Acarol 1-2:31-41

Mewis I, Ulrichs Ch (2001) Action of amorphous diatomaceous earth against different stages of the stored product pests Tribolium confusum, Tenebrio molitor, Sitophilus granaries and Plodia interpunctella. J Stored Prod Res 2:153-164 
Meyer-Kühling B, Heine J, Müller-Lindloff J, Pfister K (2007) Epidemiology of Dermanyssus gallinae and acaricidal efficacy of phoxim $50 \%$ in alternative housing systems during the laying period of hens. Parasitol Res 101:1-12

Mucha-Pelzer T, Debnath N, Goswami A, Mewis I (2008) Comparison of different silicas of natural origin as possible insecticides. Commun Agric Appl Biol Sci 3:621-628

Mul M (2016) Fact sheet: fact sheet poultry red mite in Europe. https://www.researchgate.net/publicatio n/258553789_Fact_sheet_Poultry_Red_Mite_in_Europe. Accessed 9 Apr 2020

Mullens BA, Soto D, Martin CD, Callaham BL, Gerry AC (2012) Northern fowl mite (Ornithonyssus sylviarum) control evaluations using liquid formulations of diatomaceous earth, kaolin, sulfur, azadirachtin, and Beauveria bassiana on caged laying hens. J Appl Poult Res 21:111-116

Murano T, Namiki K, Shilina K, Yasukawa H (2009) The development of resistance by Dermanyssus gallinae to commercial acaricides in Japan. J Japan Vet Med Assoc 61:287-293

Nordenfors H, Höglund J, Tauson R, Chirico J (2001) Effects of permethrin impregnated plastic strips on Dermanyssus gallinae in loose housing systems for laying hens. Vet Parasitol 102:121-131

Schulz J, Berk J, Suhl J, Schrader L, Kaufhold S, Mewis I, Hafez M, Ulrichs Ch (2014) Characterization, mode of action, and efficacy of twelve silica-based acaricides against poultry red mite (Dermanyssus gallinae) in vitro. Parasitol Res 113:3167-3175

Sparagano O, Pavlicevic A, Murano T, Camarda A, Sahibi H, Kilpinen O, Mul M, van Emous R, Le Bouquin S, Hoel K, Cafiero MA (2009) Prevalence and key figures for the poultry red mite Dermanyssus gallinae infections in poultry farm systems. Exp Appl Acarol 48:3-10

Sparagano OA, George DR, Harrington DW, Giangaspero A (2014) Significance and control of the poultry red mite, Dermanyssus gallinae. Ann Rev Entomol 59:447-466

Ulrichs Ch, Krause F, Goswami A, Kaufhold S, Mewis I (2008) Insektizide Wirkung eines natürlichen Silikates (AL06) im Vergleich zu anderen silikathaltigen Stäuben gegenüber dem Kornkäfer: Sitophilus granarius (L.). Mitt Dtsch Ges Allg Angew Ent 16:269-272

Wales AD, Carrique-Mas JJ, Rankin M, Bell B, Thind BB, Davies RH (2010) Review of the carriage of zoonotic bacteria by arthropods, with special reference to Salmonella in mites, flies and litter beetles. Zoonoses Public Health 57:299-314

Wang FF, Wang M, Xu FR, Liang DM, Pan BL (2010) Survey of prevalence and control of ectoparasites in caged poultry in China. Vet Rec 167:934-937

Wojcik AR, Grygon-Franckiewicz B, Zbikowska E, Wasielewski L (2000) Invasion of Dermanyssus gallinae (De Geer, 1778) in poultry farms in the Torun region. Wiad Parazytol 46:511-515

Zdybel J, Karamon J, Cencek T (2011) In vitro effectiveness of selected acaricides against red poultry mites (Dermanyssus gallinae, De Geer, 1778) isolated from laying hen battery cage farms localized in different regions of Poland. Bulletin- Veterinary Institute in Pulawy 55:411-416

Publisher's Note Springer Nature remains neutral with regard to jurisdictional claims in published maps and institutional affiliations.

\section{Affiliations}

\section{Christian Ulrichs $^{1}$ (D) Young Jong Han ${ }^{1} \cdot$ Magdi T. Abdelhamid ${ }^{2} \cdot$ Inga Mewis $^{1}$}

\section{Christian Ulrichs}

christian.ulrichs@hu-berlin.de

1 Faculty of Life Sciences, Division Urban Plant Ecophysiology, Humboldt-Universität zu Berlin, Lentzeallee 55, 14195 Berlin, Germany

2 Botany Department, National Research Centre, 33 EL Bohouth St. Dokki, Cairo 12622, Egypt 